\title{
Role of Leptin on Growth Hormone and Prolactin Secretion by Bovine Pituitary Explants
}

\author{
P. A. Accorsi, ${ }^{1}$ A. Munno, M. Gamberoni, R. Viggiani, M. De Ambrogi, C. Tamanini, and E. Seren \\ Dipartimento di Morfofisiologia Veterinaria e Produzioni Animali, Università di Bologna, Via Tolara di Sopra 50, 40064 Ozzano Emilia (BO), Italy
}

\section{ABSTRACT}

Leptin is an important hormone regulating nutritional status in humans and animals. Its most relevant activity is at the hypothalamic level, where it modulates food behavior, thermogenesis, and secretion of several pituitary hormones. The exact mechanisms underlying these processes are unclear. The purpose of this study was to verify whether leptin could modulate growth hormone $(\mathrm{GH})$ and prolactin (PRL) secretion acting directly on bovine pituitary cells. Adenohypophyseal explants were cultured with different concentrations of leptin (50, 250, and $500 \mathrm{ng} / \mathrm{mL}$ ); $\mathrm{GH}$ and PRL concentrations in culture media were determined by RIA. On tissues treated with $250 \mathrm{ng} / \mathrm{mL}$ of leptin, $\mathrm{GH}$ and PRL mRNA, as well as protein content, were estimated by reverse transcription-PCR and Western immunoblotting, respectively. Concentrations of GH in culture media containing 250 and $500 \mathrm{ng} / \mathrm{mL}$ of leptin were significantly higher than in controls: $1,063.5 \pm 141.2$ (mean $\pm \mathrm{SEM})$ and $1,018.8 \pm 88.4$ vs. $748.9 \pm 74.0 \mathrm{ng} / \mathrm{mg}$ of tissue, respectively, after $1 \mathrm{~h}$ of treatment. Prolactin concentrations were significantly higher in culture media containing 50,250 , and $500 \mathrm{ng} / \mathrm{mL}$ of leptin than in controls after $2 \mathrm{~h}$ of treatment $(547.1 \pm 50.3,547.5$ \pm 58.8 , and $577.0 \pm 63.7 \mathrm{vs.} 406.8 \pm 43.9 \mathrm{ng} / \mathrm{mg}$ of tissue, respectively). Tissues cultured with $250 \mathrm{ng} / \mathrm{mL}$ of leptin had significantly higher GH mRNA and lower GH protein content than controls $(389.7 \pm 17.9$ vs. $289.7 \pm$ $16.7 ; 1,601.5 \pm 90.1$ vs. $2,212.7 \pm 55.6$ arbitrary units, respectively) after $5 \mathrm{~h}$ of treatment. In contrast, no significant differences were found for PRL mRNA and protein content, possibly because of a delay in the leptin stimulation of PRL secretion. The results suggest that GH and PRL secretion in bovine pituitary explants can be directly regulated by leptin.

Key words: bovine, leptin, growth hormone, prolactin

Received September 19, 2006.

Accepted December 7, 2006.

${ }^{1}$ Corresponding author: Accorsi@vet.unibo.it

\section{INTRODUCTION}

Leptin, the product of the obesity (ob) gene (Zhang et al., 1994), is a $16-\mathrm{kDa}$ hormone that regulates feeding behavior and energy expenditure; these effects are mainly mediated by the hypothalamus (Schwartz et al., 1999). Ob/ob mice show early obesity, hyperphagia, hyperthermia, hyperinsulinemia, hyperglycemia, and other metabolic and neuroendocrine disorders (Zhang et al., 1994). Leptin was demonstrated to exert many additional effects, often as a consequence of direct peripheral actions, including modulation of lipid and carbohydrate metabolism, angiogenesis, and hematopoiesis as well as effects on both reproductive and immune systems (Fruhbeck et al., 1998; Wauters et al., 2000). Leptin is mainly synthesized by adipose tissue; however, many different tissues are effective in producing relevant amounts of this hormone, such as bone marrow, mammary and gastric epithelium, skeletal muscle, placenta, and pituitary gland (Wauters et al., 2000).

At the central nervous system level, leptin induces the release of several neuromediators acting on the hypothalamus, where they regulate feeding behavior and metabolic rate. In the peripheral tissues, leptin directly stimulates lipolysis and inhibits lipogenesis; at the same time, it is effective in modulating the response to different hormones (i.e., insulin). Finally, it reduces ingestion, increases general metabolism, and promotes a preferential use of lipids as an energy source (Zieba et al., 2005).

Expression of leptin was detected in ovine (Iqbal et al., 2000), porcine (Lin et al., 2000), and bovine (Chelikani et al., 2003) pituitary tissues, and the recognition of leptin in FSH, LH, and thyroid stimulating hormone (TSH) cells (Sone and Osamura, 2001) suggests its direct effect on the pituitary.

Growth hormone (GH) exerts many different effects on growth and development, including lipid, carbohydrate, and protein metabolism. Growth hormone secretion is decreased in $o b / o b$ mice (Larson et al., 1976), suggesting leptin involvement in the regulation of its secretion. Rat studies have shown that leptin can stimulate both basal and GH-releasing hormone (GHRH)induced GH secretion (Carro et al., 2000). In sheep, 
long-term exposure to leptin (up to $24 \mathrm{~h}$ ) led to an increase in basal GH secretion in vitro as well as an inhibition of GHRH-stimulated GH secretion in vitro (Roh et al., 1998). In swine, leptin administration stimulates GH secretion both in vivo (Barb et al., 1998) and in vitro (Saleri et al., 2004).

Prolactin (PRL) has different activities associated with growth and development; its most important metabolic function is the modulation of the fat depot and its mobilization. But, PRL plays important roles in carbohydrate metabolism. Information on the role of leptin in modulation of PRL production is relatively scarce. Prolactin secretion is decreased in $o b / o b$ mice (Larson et al., 1976), and leptin treatment of rat pituitary tissue, in vitro, stimulates PRL secretion ( $\mathrm{Yu}$ et al., 1997). Nevertheless, acute administration of leptin in rats does not alter PRL secretion and this result does not change by varying the nutritional status (Watanobe et al., 2000). This study investigated the role of leptin in GH and PRL secretion by bovine pituitary tissue in vitro.

\section{MATERIALS AND METHODS}

\section{Culture Media}

Based on previous studies, tissue culture medium 199 (M199; Sigma Chemical Co., St. Louis, MO) was supplemented as follows: M199 + HEPES (20 mM; Sigma Chemical Co.) + sodium acetate (5 mM; Sigma Chemical Co.) + fetal bovine serum (15\%, GIBCO BRLLife Technologies, Carlsbad, CA $)+$ glucose $(2 \mathrm{mg} / \mathrm{mL}$; Sigma Chemical Co.).

\section{Pituitary Explants Culture}

A total of 15 bulls (cross-breed, Limousin $\times$ Charolais) $<12$ mo of age were used; the animals were slaughtered legally in the experimental slaughterhouse of the Faculty of Veterinary Medicine at Bologna University. Immediately after slaughter, whole pituitaries were collected and transported to the laboratory in sterile M199 at $37^{\circ} \mathrm{C}$.

The dura mater was removed and the anterior portions of the pituitary were isolated and rinsed with M199. The tissue was chopped to obtain pieces of approximately $3 \times 3 \times 3 \mathrm{~mm}$ (40 to $50 \mathrm{mg}$ ). After rinsing, 3 to 4 explants were cultured in wells of a plastic culture plate (Sterilin Co., Staffordshire, UK). Explants were immediately incubated at $37^{\circ} \mathrm{C}\left(95 \%\right.$ air, $\left.5 \% \mathrm{CO}_{2}\right)$ in medium $199(2 \mathrm{~mL})$ supplemented as previously described. The time between the slaughter and the culture was $<30 \mathrm{~min}$. Leptin (human recombinant leptin, rhleptin; Sigma Chemical Co.) was added to M199 medium at 0 (control), 50 (L50), 250 (L250), or 500
(L500) ng/mL. Medium (control, L50, L250 and L500) was changed every hour for $5 \mathrm{~h}$ and stored at $-20^{\circ} \mathrm{C}$ until GH and PRL concentrations were measured. After $5 \mathrm{~h}$ of culture, L250 explants were collected, rinsed with Dulbecco's PBS (Sigma Chemical Co.), weighed, and stored at $-80^{\circ} \mathrm{C}$ until subsequent analysis by reverse transcription (RT)-PCR and Western immunoblotting.

\section{RIA}

Growth hormone and PRL concentrations in pituitary culture media were assayed by double-antibody RIA (Tamanini et al., 1985; Baratta et al., 1997). Briefly, GH and PRL were iodinated with ${ }^{125} \mathrm{I}$ according to Salacinski et al. (1981). Bovine somatotropin (Tucker Endocrine Research Institute, LLC; Tucker, GA) and bovine PRL (NIDDK-I1, Bethesda, MD) were used as labeled ligands (specific activity 32.15 and $67.12 \mu \mathrm{Ci} / \mu \mathrm{g}$ for GH and PRL, respectively). Bovine somatotropin and bovine PRL (LER 891) were used as standards. A rabbit anti-bST antiserum (NIH-GH-B13) and a rabbit anti-oPRL antiserum (LER 1790) were used at a final dilution of 1:10,000 and 1:170,000, respectively. Assay sensitivity and effective $50 \%$ dose were $0.5 \pm 0.12$ (mean $\pm \mathrm{SEM})$ and $2.56 \pm 0.24 \mathrm{ng} / \mathrm{mL}$ for $\mathrm{GH}$ and $1.30 \pm 0.25$ and $4.30 \pm 0.52 \mathrm{ng} / \mathrm{mL}$ for PRL. The intra- and interassay coefficients of variation were $<9$ and $15 \%$, respectively, for both assays.

\section{RT-PCR Assay}

Hormone mRNA expression was assayed by RT-PCR. Oligonucleotide primers were derived from the sequence of bovine GH and PRL mRNA (GenBank accession numbers M57764 and V00112 respectively). Primers for GH were: 5'-TCC AGA ACA CCC AGG TTG CC$3^{\prime}$ (sense) and 5'-CAT CTT CCA GCT CCC GCA TC-3' (antisense); primers for PRL were: $5^{\prime}$-GTT GCT GCG CTC CTG GAA TG-3' (sense) and 5'-TTT GCA GGG ACG GGA GTC CT-3' (antisense).

Actin primers used for normalization were derived from swine: 5'-ATC GTG CGG GAC ATC AAG GA-3' (sense) and 5'-AGG AAG GAG GGC TGG AAG AG-3' (antisense). These primers were used after the high homology between the 2 sequences ( $\geq 94 \%$; accession numbers AY550069 and NM173979, PubMed) was verified. All primers were synthesized by Invitrogen (Carlsbad, CA).

To detect the hormone expression, $1.5 \mu \mathrm{g}$ of total RNA was reversed transcribed. For GH detection, $4 \mu \mathrm{L}$ of the $\mathrm{RT}$ reaction mixture was used in each $\mathrm{PCR}$ reaction, which contained $6 \mathrm{ng} / \mathrm{mL}$ of each specific primer, 1.5 $\mathrm{mM} \mathrm{MgCl} 2,200 \mu M$ dNTPs, and 0.5 units of Taq DNA polymerase (Promega, Madison, WI) in a $50-\mu \mathrm{L}$ total 
reaction volume. Samples were amplified for 25 cycles. For PRL detection, $7 \mu \mathrm{L}$ of the RT reaction mixture were used in each PCR reaction, which contained $6 \mathrm{ng} /$ $\mathrm{mL}$ of each specific primer, $1.5 \mathrm{mM} \mathrm{MgCl}_{2}, 200 \mu M$ dNTPs, and 0.5 units of Taq DNA polymerase (Promega), in a $50-\mu \mathrm{L}$ total volume reaction. Samples were amplified for 27 cycles. Integrity of the sample was tested in a parallel assay in which the target cDNA was amplified using the primers for $\beta$-actin. Each PCR reaction was subjected to $2 \%$ agarose gel electrophoresis and the amplified products were visualized by staining with ethidium bromide. Optical density of each gel was measured (Gel Doc 1000, BioRad, Hercules, CA), expressed in arbitrary units, and normalized using the signals generated with $\beta$-actin. The presence of possible contaminants was checked by control reactions in which amplification was carried out on samples without RT in the PCR mixture.

\section{Western Immunoblot Analysis}

Growth hormone and PRL intracellular stores were assayed by Western immunoblot analysis. Tissues were homogenized in homogenization buffer $(10 \mathrm{~m} M$ Tris$\mathrm{HCl}, 200 \mathrm{~m} M$ EDTA, and $0.28 \mathrm{~m} M$ phenylmethylsulfonyl fluoride at $\mathrm{pH}$ 6.8), added bromophenol blue, and boiled for 5 min before electrophoresis on a 15\% SDSPAGE gel using a minigel apparatus (BioRad). Proteins were electrophoretically transferred onto a nitrocellulose membrane. Blots were washed in Tris-buffered saline (TBS); protein transfer was checked by staining the nitrocellulose membrane with $0.2 \%$ Ponceau Red and the gel with Coomassie Blue. Nonspecific protein binding sites on nitrocellulose membranes were blocked with $3 \%$ membrane blocking agent (Amersham Bioscience, Little Chalfont, UK) in TBS-0.1\% Tween 20 (TBST20) for $3 \mathrm{~h}$ at room temperature. The membranes were then incubated overnight at $4^{\circ} \mathrm{C}$ with a $1: 8,000$ dilution of an anti-bGH polyclonal antibody (Accurate Chemical and Scientific Corporation, Westbury, NY) or with a 1:7,000 dilution of an anti-bPRL polyclonal antibody (Upstate Biotechnology, Lake Placid, NY), in TBS-T20 with $3 \%$ membrane blocking agent.

After several washings with TBS-T20, the membranes were incubated first with a 1:100,000 dilution of a goat anti-rabbit IgG (StressGen, Victoria, BC, Canada), conjugated with biotin, and then with a 1:3,000 dilution of horseradish peroxidase-linked avidin (BioRad). The Western blots were developed using chemiluminescent substrates (SuperSignal West-Pico Chemiluminescent substrate; Pierce, Rockford, IL) according to the manufacturer's instructions. The relative protein content was determined by the density of the resultant bands using the Quantity One software (BioRad), ex- pressed in arbitrary units, and normalized using the signals generated with $\beta$-tubulin. To analyze the same blots with different antibodies, membranes were stripped and blocked again. Briefly, membranes were washed for $5 \mathrm{~min}$ in water, $5 \mathrm{~min}$ in $0.2 \mathrm{M} \mathrm{NaOH}$, and then washed again in water. After the blocking reaction, the membranes were incubated overnight at $4^{\circ} \mathrm{C}$ with a 1:3,000 dilution of anti- $\beta$-tubulin monoclonal antibody (Upstate Biotechnology).

\section{Statistical Analysis}

An ANOVA was used to evaluate the variations of hormone concentrations in M199 medium, as well as mRNA and protein content of pituitary explants after $1,2,3,4$, and $5 \mathrm{~h}$ of incubation; significant differences were analyzed by Duncan's test. Differences with $P<$ 0.05 were considered statistically significant.

\section{RESULTS}

\section{GH and PRL Secretion}

The effects of rhleptin on GH concentrations in pituitary culture media are shown in Figure 1. The L250 and L500 treatments resulted in a significant increase $(P<0.05)$ in $\mathrm{GH}$ release after the first hour of treatment. None of the treatments induced any differences from 2 to $5 \mathrm{~h}$ except for the $50 \mathrm{ng} / \mathrm{mL}$ treatment, which induced a significant increase $(P<0.05)$ in $\mathrm{GH}$ secretion at $4 \mathrm{~h}$. The effects of rhleptin on PRL concentrations in pituitary culture media are shown in Figure 2. All leptin concentrations significantly $(P<0.05)$ increased PRL secretion only at $2 \mathrm{~h}$ of treatment.

\section{GH and PRL mRNA Expression}

The effects of L250 for $5 \mathrm{~h}$ on GH mRNA expression are reported in Figure 3 ; leptin significantly $(P<0.01)$ stimulated mRNA for GH. Prolactin mRNA levels after rhleptin treatments are shown in Figure 4; no significant differences were observed between pituitary explants treated with rhleptin and controls.

\section{GH and PRL Intracellular Stores}

Figure 5 shows the relative GH (protein) content determined by the density of the Western immunoblotting, expressed in arbitrary units, and normalized using the signals generated with $\beta$-tubulin. Leptin induced a significant reduction $(P<0.01)$ of GH content in pituitary explants. The intracellular levels of PRL are reported in Figure 6; no significant differences between pituitary explants treated with rhleptin and controls were observed. 


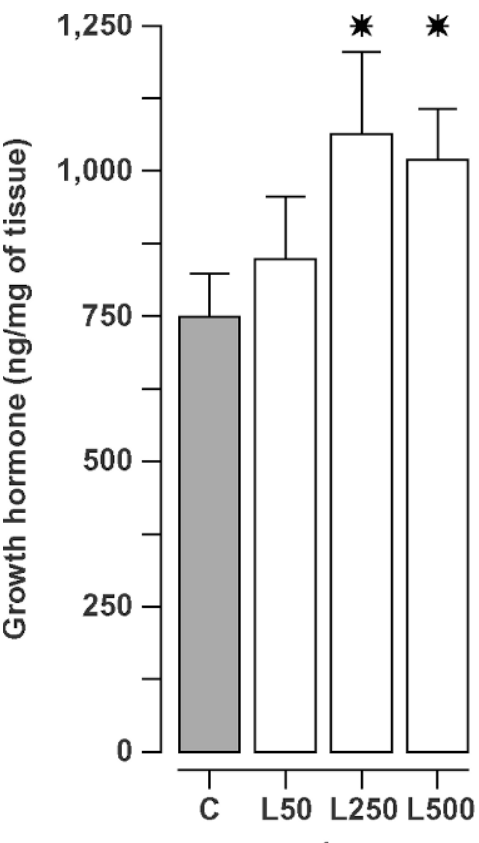

1

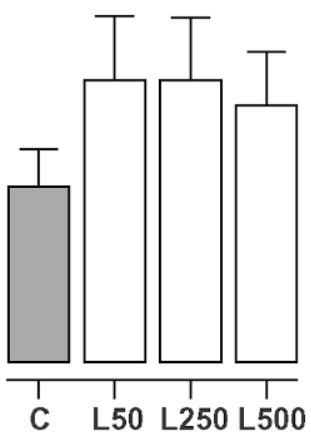

2

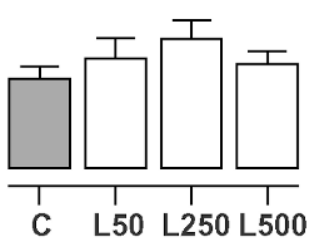

3

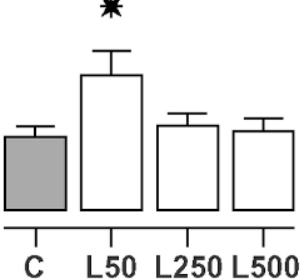

4

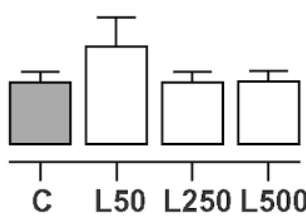

5

Incubation time $(\mathrm{h})$

Figure 1. Concentrations of bovine growth hormone (expressed as ng/mg of tissue, mean \pm SEM) in the medium of pituitary explants treated with 50, 250, or $500 \mathrm{ng} / \mathrm{mL}$ of leptin (L50, L250, and L500) after 1,2,3,4, and $5 \mathrm{~h}$ of incubation. The asterisks indicate significant differences $(P<0.05)$ between treated explants and explants cultured with medium 199 without leptin (control, C) at the same incubation time.

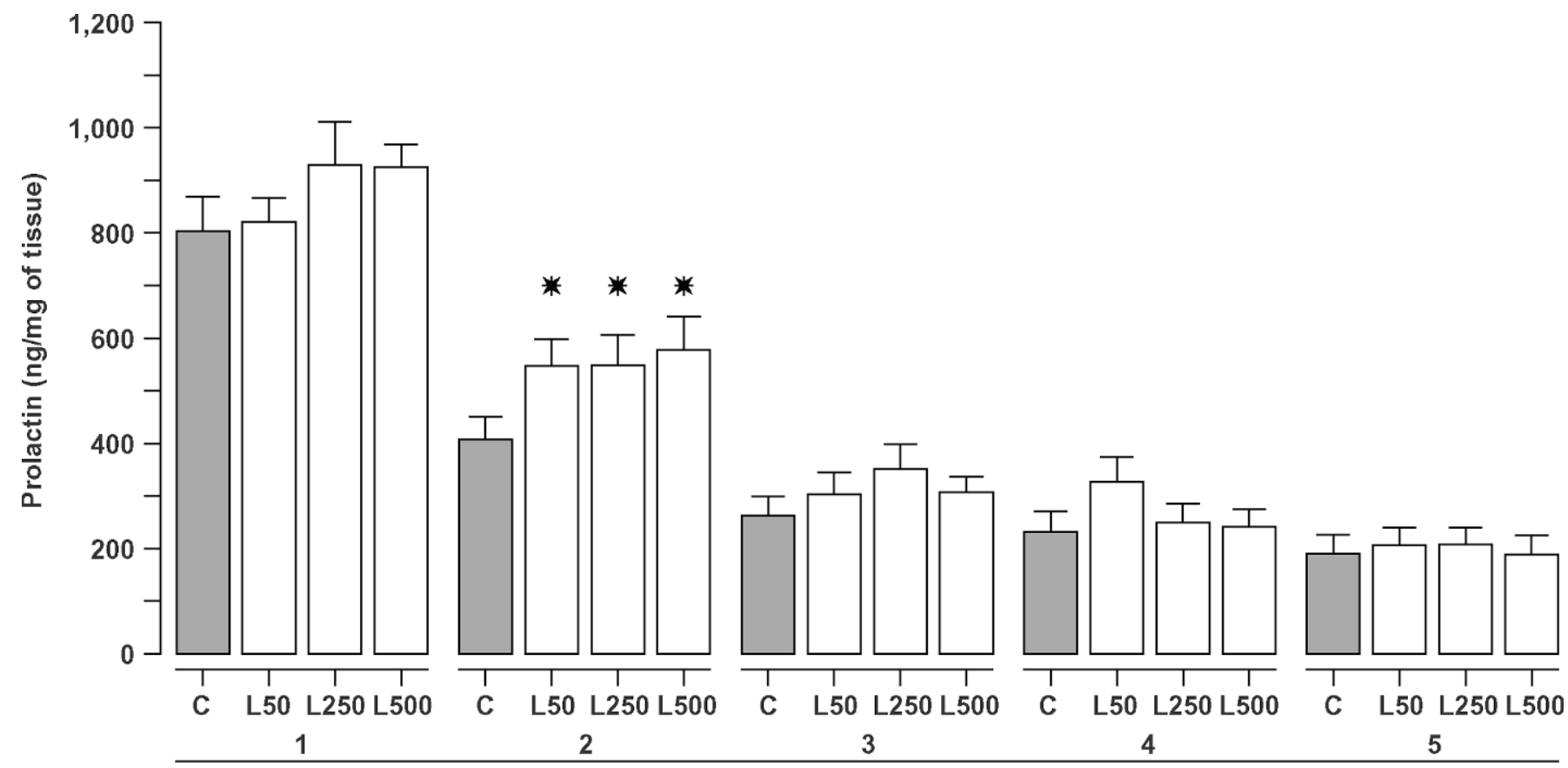

Incubation time (h)

Figure 2. Concentrations of bovine prolactin (expressed as ng/mg of tissue, mean \pm SEM) in the medium of pituitary explants treated with 50,250 , or $500 \mathrm{ng} / \mathrm{mL}$ of leptin (L50, L250, and L500) after 1,2,3,4, and $5 \mathrm{~h}$ of incubation. The asterisks indicate significant differences $(P<0.05)$ between treated explants and explants cultured with medium 199 without leptin (control, C) at the same incubation time. 
A)

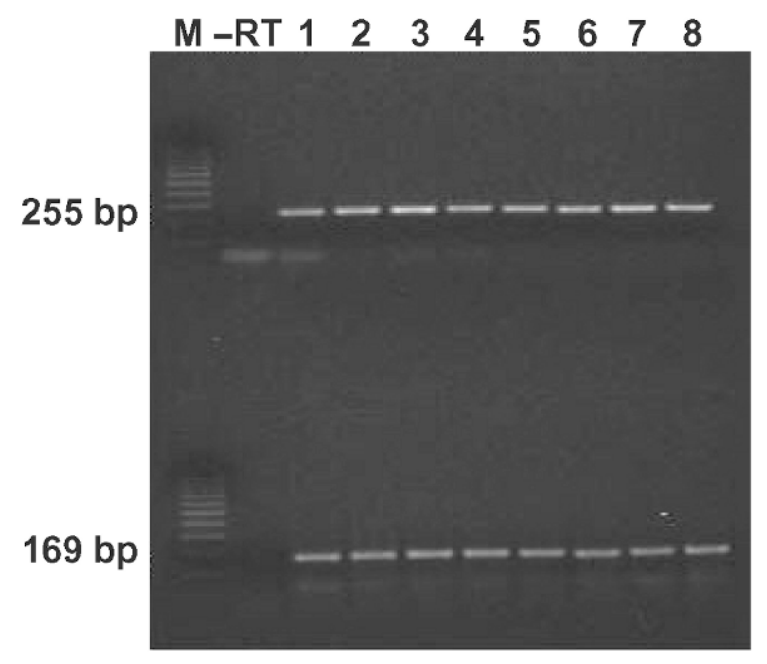

B)

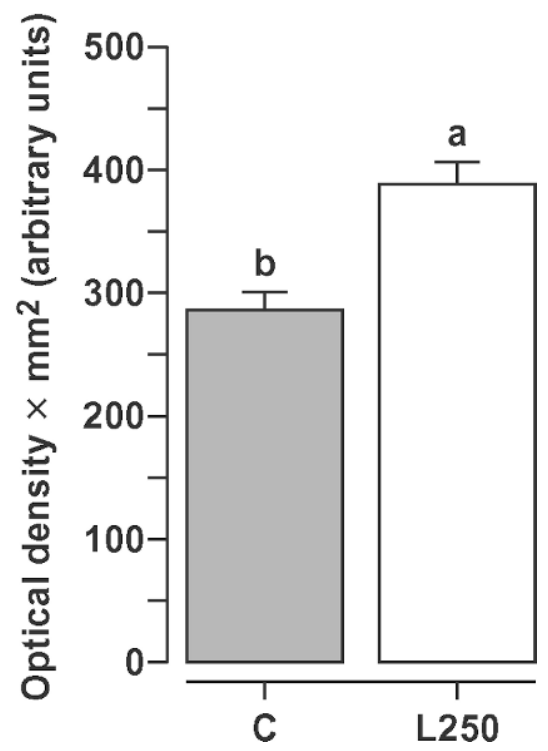

Figure 3. A) Representative agarose gel electrophoresis of reverse transcription-PCR analysis of bovine growth hormone (top) and $\beta$ actin mRNA (bottom) from bovine pituitary explants cultured with different hormonal treatments after $5 \mathrm{~h}$ of incubation. Lanes: $\mathrm{M}=$ standard weight marker; $-\mathrm{RT}=$ without $\mathrm{cDNA} ; 1,2,3,4=$ explants cultured with medium 199 without hormones (controls); $5,6,7,8=$ explants treated with $250 \mathrm{ng} / \mathrm{mL}$ of recombinant human leptin. B) Optical density (means \pm SEM, 15 replicates) of electrophoretic bands expressed in arbitrary units and normalized using the signals generated with $\beta$-actin. $\mathrm{C}=$ control explants cultured with medium 199 without hormones; L250 = explants treated with $250 \mathrm{ng} / \mathrm{mL}$ of recombinant human leptin. ${ }^{\mathrm{a}, \mathrm{b}}$ Different letters indicate a significant difference $(P<0.01)$

A)

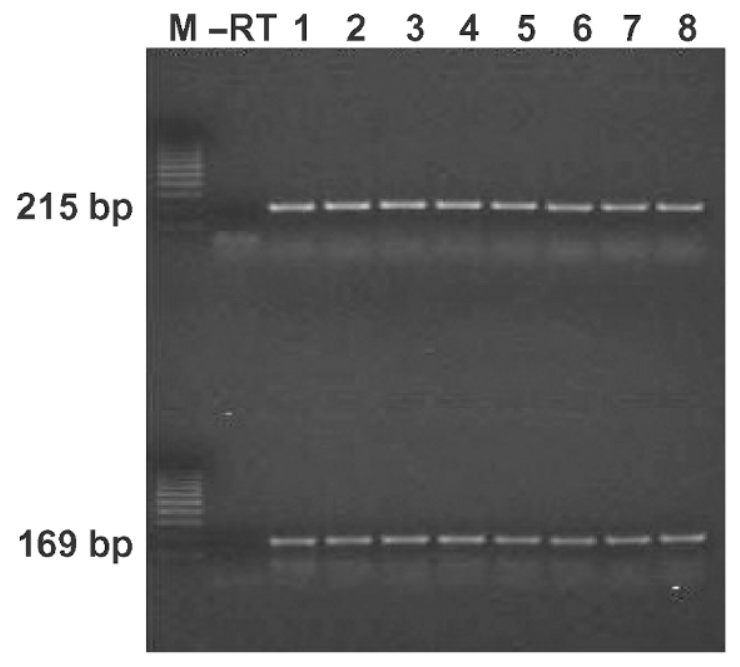

B)

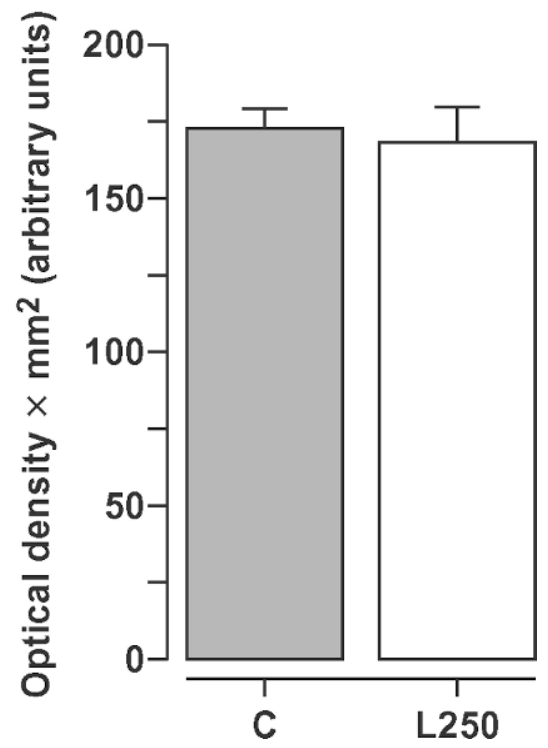

Figure 4. A) Representative agarose gel electrophoresis of the reverse transcription-PCR analysis of bovine prolactin (top) and $\beta$-actin mRNA (bottom) from bovine pituitary explants cultured with different hormonal treatments after $5 \mathrm{~h}$ of incubation. Lanes: $\mathrm{M}=$ standard weight marker; $-\mathrm{RT}$ = without $\mathrm{cDNA} ; 1,2,3,4=$ explants cultured with medium 199 without hormones (controls); $5,6,7,8=$ explants treated with $250 \mathrm{ng} / \mathrm{mL}$ of recombinant human leptin. B) Optical density (means \pm SEM, 15 replicates) of electrophoretic bands expressed in arbitrary units and normalized using the signals generated with $\beta$-actin. $\mathrm{C}=$ control explants cultured with medium 199 without hormones; L250 = explants treated with $250 \mathrm{ng} / \mathrm{mL}$ of recombinant human leptin. 
A)

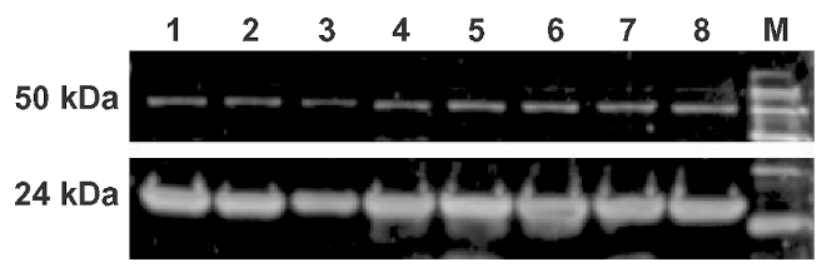

B)

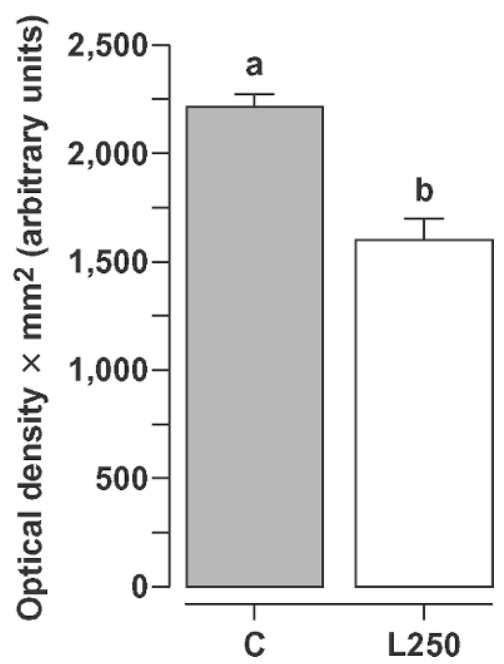

Figure 5. A) Representative agarose gel electrophoresis of Western blot analysis of bovine growth hormone (bottom) and $\beta$-tubulin (top) in bovine pituitary explants cultured with different hormonal treatments. Lanes: $\mathrm{M}=$ standard weight marker; $1,2,3,4=$ explants cultured with medium 199 without hormones (controls); 5, 6, 7, 8 = explants treated with $250 \mathrm{ng} / \mathrm{mL}$ of recombinant human leptin. B) Optical density (means \pm SEM, 15 replicates) of electrophoretic bands expressed in arbitrary units and normalized using the signals generated with $\beta$ tubulin. $\mathrm{C}=$ control explants cultured with medium 199 without hormones; L250 = explants treated with $250 \mathrm{ng} / \mathrm{mL}$ of recombinant human leptin. ${ }^{\mathrm{a}, \mathrm{b}}$ Different letters indicate a significant difference $(P<0.01)$.

\section{DISCUSSION}

Our results demonstrate that leptin is effective in stimulating GH secretion; in fact, both L250 and L500 treatments for $1 \mathrm{~h}$ significantly increased GH levels. Furthermore, RT-PCR analysis provided evidence of an increase in $\mathrm{GH}$ gene transcription after $5 \mathrm{~h}$ of treatment, indicating a possible positive effect on $\mathrm{GH}$ synthe-
A)

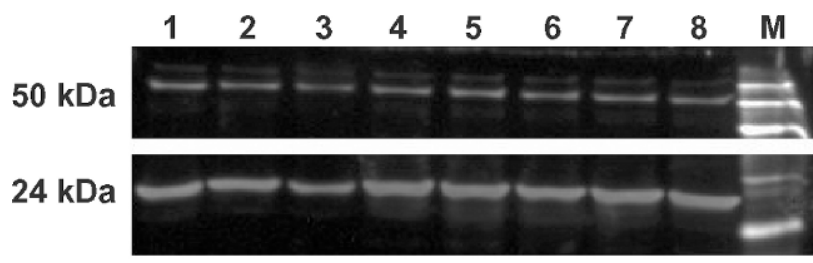

B)

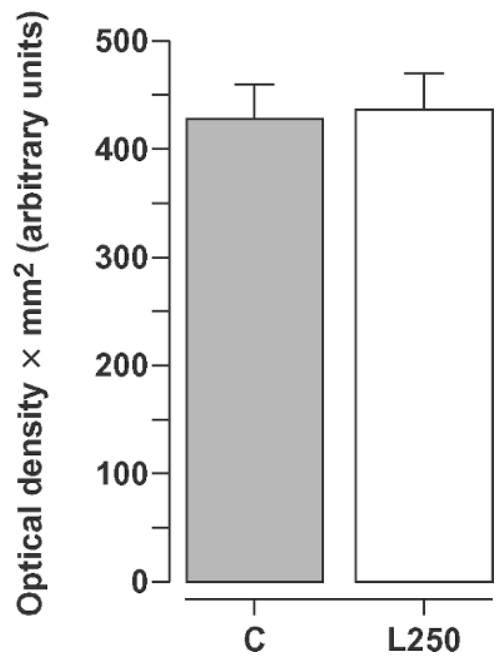

Figure 6. A) Representative agarose gel electrophoresis of Western blot analysis of bovine prolactin (bottom) and $\beta$-tubulin (top) in bovine pituitary explants cultured with different hormonal treatments after $5 \mathrm{~h}$ of incubation. Lanes: $\mathrm{M}=$ standard weight marker; $1,2,3,4=$ explants cultured with medium 199 without hormones (controls); 5, 6, 7, 8 = explants treated with $250 \mathrm{ng} / \mathrm{mL}$ of recombinant human leptin. B) Optical density (means \pm SEM, 15 replicates) of electrophoretic bands expressed in arbitrary units and normalized using the signals generated with $\beta$-tubulin. $\mathrm{C}=$ control explants cultured with medium 199 without hormones; L250 = explants treated with $250 \mathrm{ng} / \mathrm{mL}$ of recombinant human leptin. 
sis; this hypothetical increase in de novo synthesis did not seem sufficient to restore GH released because GH content in leptin-treated explants was lower than in controls. To our knowledge, the experimental evidence of a direct effect of leptin on bovine pituitary cells is lacking and this experiment has shown that leptin influences GH and PRL secretion by acting directly on the bovine pituitary.

These findings agree with those obtained using pig pituitaries by Saleri et al. (2004), who observed the highest GH secretion 40 min after treating cells with rhleptin; after $2 \mathrm{~h}, \mathrm{GH}$ concentrations in culture medium were similar to those in controls. Similar results were reported by Baratta et al. (2002), who found that rhleptin (alone or in association with GHRH) added to pig pituitary cells cultured for 4 or $24 \mathrm{~h}$ significantly stimulated GH secretion in both incubation periods. Also, Barb et al. (1998) reported that leptin, individually or in combination with GHRH, significantly increased GH secretion in pituitary cells from prepubertal gilts. Nonetheless, our results differ in part from those obtained by Zieba et al. (2003) in cows and Roh et al. (1998) in sheep. Indeed, Zieba et al. (2003) reported that recombinant ovine leptin (roleptin) reduced basal GH secretion by perifused adenohypophyseal explants from mature, ovariectomized, and estradiol-implanted cows.

In rats, Mizuno et al. (1999) demonstrated that high (but not physiological) concentrations of leptin increased GH secretion; $200 \mathrm{ng} / \mathrm{mL}$ of leptin stimulated $\mathrm{GH}$ release only in the presence of GHRH. The stimulatory effect we observed agrees well with experimental results in rodents, sheep, swine, and cow in which leptin stimulated GH secretion by direct action on the pituitary gland as well as by hypothalamic action. Intracerebroventricular infusion or i.v. administration of leptin stimulated basal GH secretion, GH pulse amplitude, and GHRH-induced GH release in the pig (Barb et al., 1998).

The increase in GH mRNA synthesis detected after $5 \mathrm{~h}$ in pituitaries treated with $250 \mathrm{ng} / \mathrm{mL}$ of leptin in this study has also been observed in the pig (Baratta et al., 2002); those authors found that GH gene expression was significantly increased by rhleptin after $24 \mathrm{~h}$ of treatment.

Thus far, information on the role of leptin in regulating PRL secretion is meager and conflicting. In fact, leptin treatment of rat pituitaries in vitro increased PRL secretion (Yu et al., 1997), whereas acute administration of leptin in vivo did not alter PRL plasma levels irrespective of nutritional condition, and its constant infusion prevented a drop in PRL in normally fed rats (Watanobe et al., 2000). Moreover, high doses of leptin cause a further PRL increase in fasted animals; there- fore, as with other pituitary hormones, PRL seems more sensitive to leptin during undernutrition, when leptin levels are low (Tannenbaum et al., 1998). Leptin receptors on lactotrophs are scarce, so that a direct action of leptin at the pituitary level appears unlikely. Furthermore, because leptin infusion in the arcuate nucleus and median eminence stimulates PRL secretion, this control is possibly mediated by hypothalamic neurons (Watanobe and Habu, 2002).

Our results document, for the first time, that leptin stimulates PRL secretion by bovine pituitary cells, even though it does not induce stimulation of PRL mRNA synthesis or significant variation in PRL intracellular content. One possible explanation might be that $5 \mathrm{~h}$ of treatment is not sufficient to determine a significant increase in PRL intracellular content as well as in its transcription levels. Unfortunately, we did not find similar studies in the literature to compare with ours.

The response of bovine pituitary cells to leptin stimulation observed in the current study was not dose-dependent; both GH and PRL secretion were stimulated by the highest concentrations ( 250 and $500 \mathrm{ng} / \mathrm{mL}$ ). In our opinion, the L50-induced GH increase at $4 \mathrm{~h}$ was accidental. The response time to leptin was different: $1 \mathrm{~h}$ for GH secretion and $2 \mathrm{~h}$ for PRL. These results would substantiate the findings in cultures of ovine pituitary cells (Roh et al., 1998), in pig cultured pituitary cells (Barb et al., 1998; Baratta et al., 2002; Saleri et al., 2004) and in adenohypophyseal explants from cows (Zieba et al., 2003). In those reports, leptin-induced GH secretion occurred at different incubation times (from $40 \mathrm{~min}$ to $24 \mathrm{~h}$ ) and was dependent on leptin dose. Similar considerations on the effective dose and response time can be made for PRL secretion (Yu et al., 1997; Watanobe and Habu, 2002). The different response of pituitary cells is not likely limited to somatotroph or lactotroph cells. Different responses may have been due to the different physiological status (nutritional or reproductive) of the animals or to the different leptin preparations (timing, duration, and dose) used in various experiments. In this study, $250 \mathrm{ng} / \mathrm{mL}$ of leptin exerted different effects on GH and PRL mRNA synthesis; indeed, it induced a significant increase in cell content of GH mRNA after $5 \mathrm{~h}$ of culture, but did not modify PRL mRNA.

We hypothesize that GH and PRL mRNA synthesis requires different mechanisms and time, perhaps depending on changes in $\mathrm{Ca}^{2+}$ permeability and intracellular concentrations (McArdle et al., 2002) or on the activation of mediators such as inositol 1,4,5-triphospate (Takekoshi et al., 2001) or receptor desensitization (McArdle et al., 2002). Nevertheless, we cannot exclude the possibility that different physiological conditions in animals could modify the sensitivity of pituitary cells 
to leptin, thus changing the time necessary for mRNA synthesis. Indeed, Amstalden et al. (2004) observed a change in cell content of mRNA for SOCS-3 depending on the nutritional status of dairy cows.

Results from this study integrate those obtained in other species, particularly in sheep, concerning the action of leptin on the hypothalamic-pituitary axis. Our findings show, for the first time, that leptin plays a role in the autocrine or paracrine modulation of somatotrophs and lactotrophs, besides the well-known indirect effects via the hypothalamus. That suggests that leptin can participate in the modulation of the somatotroph and lactotroph axis, irrespective of the action of other hypothalamic neurotransmitters released as a consequence of modifications of energy balance, adipose tissue, metabolic condition, and food assumption. Furthermore, we hypothesize that this direct effect of leptin on both somatotrophs and lactotrophs, together with the well-known leptin effects on the hypothalamic-pituitary-adrenal and hypothalamic-pituitary-gonadal axis, strengthens other neuroendocrine signals involved in the homeostatic regulation of the organism. Nonetheless, further studies in the bovine are necessary to fully understand the mechanisms of this regulation in vivo. It is important to consider both the hypothalamic effects on GH and PRL secretion and the possible alterations in response to different nutritional states. Secretions of leptin, GH, and PRL are influenced by other hormones (i.e., insulin) and metabolites (i.e., glucose, NEFA, and AA). Furthermore, changes in nutritional status were shown to modify the number of leptin receptors (Saleri et al., 2006), thus changing the sensitivity of pituitary cells.

\section{CONCLUSIONS}

This in vitro study demonstrates a type of regulation very difficult to substantiate otherwise; in the in vivo systems, too many variables can significantly modify pituitary secretion of GH and PRL. Overall, our data suggest that, even in bovine species, leptin is effective in directly modulating both GH and PRL secretion acting at the pituitary level, in addition to an indirect action on pituitary activity.

\section{ACKNOWLEDGMENTS}

This work was supported by MIUR-FIRB RBNE013XSJ_001 and COFIN grants.

\section{REFERENCES}

Amstalden, M., T. E. Spencer, P. G. Harms, D. H. Keisler, and G. L. Williams. 2004. Expression of leptin receptor and suppressor of cytokine signaling-3 in adenohyphysis of normal-fed and fasted cows. 37th Mtg., Society for the Study of Reproduction, Vancouver, CA. 107:61.

Baratta, M., R. Saleri, G. L. Mainardi, D. Valle, A. Giustina, and C. Tamanini. 2002. Leptin regulates growth hormone gene expression and secretion and nitric oxide production in pig pituitary cells. Endocrinology 143:551-557.

Baratta, M., R. Saleri, C. Mascadri, D. H. Coy, A. Negro-Vilar, C. Tamanini, and A. Giustina. 1997. Modulation by galanin of growth hormone and gonadotropin secretion from perifused pituitary and median eminence of prepubertal male calves. Neuroendocrinology 66:271-277.

Barb, C. R., X. Yan, M. J. Azain, R. R. Kraeling, G. B. Rampacek, and T. G. Ramsay. 1998. Recombinant porcine leptin reduces feed intake and stimulates growth hormone secretion in swine. Domest. Anim. Endocrinol. 15:77-86.

Carro, E., L. Seoane, R. Senaris, F. Casanueva, and C. Dieguez. 2000. Leptin increases in vivo GH responses to GHRH and GH-releasing peptide-6 in food-deprived rats. Eur. J. Endocrinol. 142:66-70.

Chelikani, P., D. Glimm, and J. Kennelly. 2003. Tissue distribution of leptin and leptin receptor mRNA in the bovine. J. Dairy Sci. 86:2369-2372.

Fruhbeck, G., M. Aguado, J. Gomez-Ambrosi, and J. A. Martinez. 1998. Lipolytic effect of in vivo leptin administration on adipocytes of lean and ob/ob mice, but not db/db mice. Biochem. Biophys. Res. Commun. 250:99-102.

Iqbal, J., S. Pompolo, R. V. Considine, and I. J. Clarke. 2000. Localisation of leptin receptor-like immunoreactivity in the corticotropes, somatotropes, and gonadotropes in the ovine anterior pituitary. Endocrinology 141:1515-1520.

Larson, B., Y. Sinha, and W. Vanderlaan. 1976. Serum growth hormone and prolactin during and after the development of the obesehyperglycemic syndrome in mice. Endocrinology 98:139-145.

Lin, J., C. R. Barb, R. L. Matteri, R. R. Kraeling, X. Chen, R. J. Meinersmann, and G. B. Rampacek. 2000. Long form leptin receptor mRNA expression in the brain, pituitary, and other tissues in the pig. Domest. Anim. Endocrinol. 19:53-61.

McArdle, C., J. Franklin, L. Green, and J. Hislop. 2002. Signalling, cycling and desensitisation of gonadotrophin-releasing hormone receptors. J. Endocrinol. 173:1-11.

Mizuno, I., Y. Okimura, Y. Takahashi, H. Kaji, H. Abe, and K. Chihara. 1999. Leptin stimulates basal and GHRH-induced GH release from cultured rat anterior pituitary cells in vitro. Kobe J. Med. Sci. 45:221-227.

Roh, S., I. J. Clarke, R. Xu, J. W. Goding, K. Loneragan, and C. Chen. 1998. The in vitro effect of leptin on basal and growth hormonereleasing hormone-stimulated growth hormone secretion from the ovine pituitary gland. Neuroendocrinology 68:361-364.

Salacinski, P. R. P., C. McLean, J. E. C. Sykes, V. V. Clement-Jones, and P. J. Lowry. 1981. Iodination of proteins, glycoproteins and peptides using a solid-phase oxidizing agent, 1,3,4,6-tetracloro 3a-6a diphenyl glycuril (Iodogen). Anal. Biochem. 117:136-146.

Saleri, R., A. Giustina, C. Tamanini, D. Valle, A. Burattin, W. B. Wehrenberg, and M. Baratta. 2004. Leptin stimulates growth hormone secretion via a direct pituitary effect combined with a decreased somatostatin tone in a median eminence-pituitary perifusion study. Neuroendocrinology 79:221-228.

Saleri, R., F. Grasselli, V. Cavalli, and C. Tamanini. 2006. Leptin and its receptor expression in swine pituitaries cultured under deprived conditions. Vet. Res. Commun. (Suppl. 1):207-209.

Schwartz, M. W., D. G. Baskin, K. J. Kayala, and S. C. Woods. 1999. Model for the regulation of energy balance and adiposity by the central nervous system. Am. J. Clin. Nutr. 69:584-596.

Sone, M., and R. Y. Osamura. 2001. Leptin and the pituitary. Pituitary $4: 15-23$

Takekoshi, K., K. Ishii, Y. Kawakami, K. Isobe, T. Nanmoku, and T. Nakai. 2001. Ca2+ mobilization, tyrosine hydroxylase activity, and signaling mechanisms in cultured porcine adrenal medullary chromaffin cells: Effects of leptin. Endocrinology 142:290-298. 
Tamanini, C., G. Bono, F. Cairoli, and F. Chiesa. 1985. Endocrine responses induced in anestrous goats by the administration of different hormones after a fluorogestone acetate treatment. Anim. Reprod. Sci. 9:357-364.

Tannenbaum, G., W. Gurd, and M. Lapointe. 1998. Leptin is a potent stimulator of spontaneous pulsatile growth hormone (GH) secretion and the GH response to GH-releasing hormone. Endocrinology 139:3871-3875.

Watanobe, H., and S. Habu. 2002. Leptin regulates growth hormonereleasing factor, somatostatin, and alpha-melanocyte-stimulating hormone but not neuropeptide $\mathrm{Y}$ release in rat hypothalamus in vivo: Relation with growth hormone secretion. J. Neurosci. 22:6265-6271.

Watanobe, H., H. B. Schioth, and T. Suda. 2000. Stimulation of prolactin secretion by chronic, but not acute, administration of leptin in the rat. Brain Res. 887:426-431.
Wauters, M., R. V. Considine, and L. F. Van Gaal. 2000. Human leptin: From an adipocyte hormone to an endocrine mediator. Eur. J. Endocrinol. 143:293-311.

Yu, W. H., M. Kimura, A. Walczewska, S. Karanth, and S. M. McCann. 1997. Role of leptin in hypothalamic-pituitary function. Proc. Natl. Acad. Sci. USA 94:1023-1028.

Zhang, Y., R. Proenca, M. Maffei, M. Barone, L. Leopold, and J. M. Friedman. 1994. Positional cloning of the mouse obese gene and its human homologue. Nature 372:425-432.

Zieba, D., M. Amstalden, S. Morton, J. Gallino, J. Edwards, P. Harms, and G. Williams. 2003. Effects of leptin on basal and GHRHstimulated GH secretion from the bovine adenohypophysis are dependent upon nutritional status. J. Endocrinol. 178:83-89.

Zieba, D. A., M. Amstalden, and G. L. Williams. 2005. Regulatory roles of leptin in reproduction and metabolism: A comparative review. Domest. Anim. Endocrinol. 29:166-185. 